\title{
Commentary: A life worth living
}

\author{
Marian R. Hohenwarter, BS, and Chadrick E. Denlinger, MD
}

\footnotetext{
From the Division of Cardiothoracic Surgery, Department of Surgery, Medical University of South Carolina, Charleston, SC

Disclosures: Authors have nothing to disclose with regard to commercial support.

Received for publication March 7, 2019; accepted for publication March 8, 2019; available ahead of print April $17,2019$.

Address for reprints: Chadrick E. Denlinger, MD, Division of Cardiothoracic Surgery, Department of Surgery,

Medical University of South Carolina, 114 Doughty St, Charleston, SC 29425 (E-mail: denlinge@ musc.edu). J Thorac Cardiovasc Surg 2019;158:579-80

0022-5223/\$36.00

Copyright (C 2019 by The American Association for Thoracic Surgery

https://doi.org/10.1016/j.jtcvs.2019.03.017
}

A central movement in medicine through the past years has appropriately focused on value. Although difficult to define, value is something that we strive for, even if its definition is as loose as Supreme Court Justice Potter Stewart's definition of obscenity, which was "I know it when I see it." Because a high-value outcome should be the goal for each patient, discrete and objective value measures are necessary for honest self-assessment and to serve as a compass for improvement. The Society of Thoracic Surgeons (STS) General Thoracic Surgery Database remains a valuable tool for assessing surgical outcomes, but the short-term follow-up limits its ability to determine quality.

For example, one could safely get an octogenarian marginal surgical candidate through an esophagectomy without any major complication, but leave the patient so deconditioned as to be discharged to a rehabilitation facility without ever regaining the strength for independent living. According to current STS metrics, this case would appear as a win. It is unclear, however, whether this major operation afforded the patient any quality life, and one may question whether the patient might have been able to enjoy more time without the operation. Although assessment of mortality and major morbidities are important binary means of determining success, exclusive focus on these variables may ignore other important measures of quality of life.

Several studies demonstrate that operative mortality at 90 days differs significantly from 30-day mortality. ${ }^{1}$ In some cases, the 90-day mortality may even be double that observed at 30 days. ${ }^{2}$ Such a large discrepancy in mortality at these time points implies that there is an even larger cohort of debilitated patients with unmeasured complications. Not only does this diminish the value of the care that the patients have received, it also illustrates that value may not be accurately captured by the current STS comparator.

In another recent publication, Fernandez and colleagues ${ }^{3}$ also addressed the question of value by comparing shortterm operative results with long-term oncologic outcomes and found essentially no correlation. This raises the obvious question as to what is the value of an operation that the

\section{References}

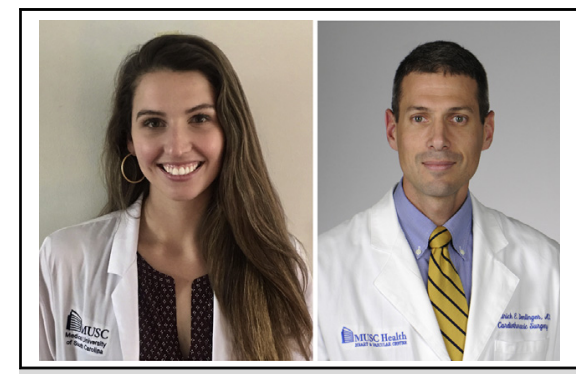

Marian R. Hohenwarter, BS (left), and Chadrick E. Denlinger, MD (right)

Central Message

There are significant differences between shortand long-term outcomes after oncologic procedures. Long-term outcomes are likely better measures of value.

See Article page 570.

patient gets through safely if we fail to achieve the oncologic objectives that were the reason for the procedure. Similarly, Onaitis and associates ${ }^{4}$ created a long-term prediction model for lung cancer resections by linking the STS General Thoracic Surgery Database with Medicare data. ${ }^{4}$ These results revealed several modifiable risk factors that contribute to long-term mortality and therefore value that are not accounted for in the STS General Thoracic Surgery Database. Others have contributed to the conversation the importance of including aspects of long-term outcomes as quality metrics, rather than focusing solely on short-term morbidity and mortality. ${ }^{5,6}$ Collectively, these data and commentaries indicate that 30-day outcomes probably do not adequately measure quality for oncologic surgery as viewed from the patients' perspective. We need simultaneously to focus on minimizing operative morbidity and mortality while also maximizing oncologic benefits and expediting our patients' return to a life worth living.

1. Moore CB, Cox ML, Mulvihill MS, Klapper J, D’Amico TA, Hartwig MG. Chal lenging 30-day mortality as a site-specific quality metric in non-small cell lung cancer. J Thorac Cardiovasc Surg. 2019;158:570-8.e2.

2. Quero-Valenzuela F, Piedra-Fernández I, Hernández-Escobar F, MartínezCeres M, Romero-Palacios PJ, De Guevara AC, et al. Half the deaths after surgery for lung cancer occur after discharge. Surg Oncol. 2018;27:630-4. Erratum in: Surg Oncol. February 12, 2019 [Epub ahead of print].

3. Fernandez FG, Kosinski AS, Tong BC, Furnary AP, Feng L, Onaitis M, et al. Lack of correlation between short- and long-term performance after lung cancer surgery. J Thorac Cardiovasc Surg. 2019;157:1633-43.e3. 
4. Onaitis MW, Furnary AP, Kosinsky AS, Kim S, Boffa D, Tong BC, et al. Prediction of long-term survival after lung cancer surgery for patients in the Society of Thoracic Surgeons General Thoracic Surgery database. Ann Thorac Surg. 2018; 105:309-16.
5. Brunelli A. Short-term outcomes do not capture the real value of lung cancer surgery. J Thorac Cardiovasc Surg. 2018;155:1311-2.

6. Brandt WS, Isbell JM, Jones DR. Defining quality in the surgical care of lung cancer patients. J Thorac Cardiovasc Surg. 2017;154:1397-403. 